\title{
Trends Associated with Stillbirth in a Maternity Hospital School in the North Zone of São Paulo: A Cross-Sectional Study
}

\section{Tendências associadas à natimortalidade em uma maternidade- escola na zona norte de São Paulo: um estudo transversal}

\author{
Raissa Magalhães de Mendonça Fonseca ${ }^{1}$ Carolina Laila Garcia ${ }^{1}$ Talita Sampaio Angimahtz ${ }^{1}$ \\ Cindy Fazio Battaglia ${ }^{1}$ Elisa Chalem ${ }^{2}$ Nelson Sass ${ }^{1,2(10}$

\footnotetext{
${ }^{1}$ Maternity Hospital School of Vila Nova Cachoeirinha, São Paulo, SP, Brazil.

2 Paulista Medical School, Universidade Federal de São Paulo, São
} \\ Paulo, SP, Brazil \\ Address for correspondence Nelson Sass, MD, PhD, Rua Umberto \\ Boccioni, 210, São Paulo, SP, 02441-150, Brazil \\ (e-mail: nelsonsa.alp@terra.com.br).
}

Rev Bras Ginecol Obstet 2019;41:597-606.

\begin{abstract}
Keywords

- stillbirth

- epidemiology

- primary health care

- prenatal care

- pregnancy high-risk

Objective To evaluate conditions associated with stillbirth (SB), and possible trends related with it, in a maternity hospital school in the North zone of São Paulo.

Methods An observational, cross-sectional study conducted at the Hospital Maternidade-escola de Vila Nova Cachoeirinha with 1,139 SBs in the period of 2003 to 2017. Cases of intermediate SB (ISB) (weight between 500 and $999 \mathrm{~g}$ ) and late SB (LSB) (weight $\geq 1,000 \mathrm{~g}$ ) were compared. We evaluated clinical data, laboratory tests, and fetal and placental studies. Data were stored in Windows Excel (Microsoft Corp., Redmond, WA, USA) worksheets, according to which graphs and tables were constructed. We used the statistical software SPSS for Windows version 18.0 (SPSS In., Chicago, IL, USA), estimating the prevalence ratio (PR) and odds ratio (OR), considering the $95 \%$ confidence interval $(95 \% \mathrm{Cl})$.

Results The general SB rate was $11.9 \%$, and the in-hospital SB rate was $2.8 \%$. Pregnant women younger than 16 years of age were more likely to have ISB (OR $0.32,0.15-$ 0.76 ), while patients older than 40 years old had a higher chance of LSB (PR $0.85,0.72$ 0.99). A total of $25.7 \%$ of the general population did not have prenatal care, and $77.1 \%$ of the cases presented fetal death at admission. The cases of ISB had a statistically significant association with home birth (OR 0.61, 0.46-0.80). Cesarean section was performed in $16.1 \%$ of the subjects, and misoprostol was the most used method for induction. Necropsy and placental study of the fetuses were performed, respectively, in $94.2 \%$ and $97.3 \%$ of the cases. Associated causes were not identified in $22.1 \%$ of the cases, and the main causes identified were amniotic sac infections (27.9\%), fetal malformations (12.5\%), placental abruption (11.2\%), hypertensive syndromes (8.5\%), and maternal syphilis (3.9\%), the latter with an increasing trend.
\end{abstract}

received

March 8, 2019

accepted

June 6, 2019
DOI https://doi.org/

10.1055/s-0039-1693984. ISSN 0100-7203.
Copyright $\odot 2019$ by Thieme Revinter

Publicações Ltda, Rio de Janeiro, Brazil
License terms

(c) (1) 
Conclusion Among the factors associated to SB were: hypertensive syndromes, amniotic sac infections, fetal malformations, placental abruption and syphilis. There was a growing trend in the number of cases of syphilis, which translates an alert. Diagnostic limitations justify indeterminate causes.

\section{Resumo}

\author{
Palavras-chave \\ - natimorto \\ - epidemiologia \\ - atenção primária à \\ saúde \\ - cuidado pré-natal \\ - gravidez de alto risco
}

Objetivo Avaliar aspectos relacionados à ocorrência da condição de natimortalidade em uma maternidade-escola na zona norte de São Paulo e possíveis tendências associadas aos fatores causais.

Métodos Estudo observacional, transversal, realizado no Hospital Maternidadeescola Vila Nova Cachoeirinha com 1.139 óbitos fetais (OF) no período de 2003 a 2017. Foram comparados os casos de OF intermediários (OFI) (peso entre 500 e $999 \mathrm{~g}$ ) e OF tardios (OFT) ( $\geq 1,000 \mathrm{~g}$ ). Avaliamos dados clínicos, exames laboratoriais, e estudos do feto e da placenta; estes foram armazenados em planilhas de Windows Excel (Microsoft Corp., Redmond, WA USA0, utilizando-se para avaliação estatística o programa SPSS v.18 (SPSS Inc., Chicago, IL, EUA). Foram ainda estimadas a razão de prevalência (RP) e a razão de chances (RC), com intervalo de confiança de 95\% (IC 95\%). Resultados O coeficiente de natimortalidade geral foi de 11,9\% e o intra-hospitalar foi de $2,8 \%$. Gestantes com menos de 16 anos de idade apresentaram maior chance de ter OFI (RC $0.32,0.15-0.76$ ) enquanto que pacientes com mais de 40 anos de idade apresentaram maior chance de OFT (RP 0,85; 0,72-0,99). Não fizeram prenatal $25,7 \%$ da população geral, sendo que em $77,1 \%$ dos casos, a morte fetal já tinha sido apresentada na internação. Os casos de OFI apresentaram associação estatisticamente significante com parto domiciliar ( $R C 0,42 ; 0,23-0,75$ ). A cesárea foi realizada em $16,1 \%$ das pacientes, sendo o misoprostol o método mais utilizado para indução. Necropsia foi feita em $94,2 \%$ dos fetos, e $97,3 \%$ das placentas foram para estudo. As causas associadas não foram identificadas em $22,1 \%$ dos casos, sendo que as principais causas identificadas foram infecções do saco amniótico e membranas $(27,9 \%)$, malformações $(12,5 \%)$, descolamento prematuro de placenta $(11,2 \%)$, síndromes hipertensivas (8,5\%), e sífilis (3,9\%), sendo esta última com uma tendência crescente. Conclusão Destacaram-se como fatores associados à natimortalidade: síndromes hipertensivas, corioamnionites, malformações fetais, descolamento placentário e sífilis. Houve tendência de aumento no número de casos de sífilis, o que traduz uma alerta. Limitações diagnósticas justificam as causas indeterminadas.

\section{Introduction}

Stillbirth (SB) is a reproductive tragedy not only related to immediate maternal risks inherent to clinical management but also to psychosocial problems, such as depression, posttraumatic stress, social stigmatization, and difference in the quality of live of families. ${ }^{1}$

Each year, at least 2.6 million SBs occur worldwide, especially in poor or developing countries. ${ }^{2}$ According to the Ministry of Health of Brazil, a total of 351,912 SBs was registered during the period from 2006 to 2016. From this total, 129,173 occurred in the Southeast region, with a monthly average of 11,000 occurrences. ${ }^{3}$ Additionally, many epidemiological studies have registered that most SBs would be susceptible to prevention. ${ }^{4}$

Despite the negative impacts they produce, SBs are unattractive from the point of view of clinical research, and most of the time, investigations are very superficial and have a very limited extent, affecting their understanding and implications. Promoting the educational audit of SB cases, performed by a technically qualified team and with availability of resources, such as laboratory evaluations, placenta study, and necropsies, can produce consistent information to understand the factorswith $\mathrm{SB}$ and to support prevention strategies. ${ }^{5}$

The assessment of the causes associated with SB remains a major challenge for understanding the problem at a population scale. The recurrent diagnosis of intrauterine hypoxia as a cause of death hardly contributes to understanding the phenomenon. In addition, many studies do not specify whether hypoxia occurred before or during birth. ${ }^{6}$

Thus, SB rates are valuable indicators related to the quality of obstetric care globally, and they contribute to the support of public health planning processes. The more precise the 
identification of the associated causes, the better strategies can be planned to improve the quality of prenatal care. ${ }^{7}$

Considering that, in Brazil, more than $98.0 \%$ of deliveries are performed in hospitals, the amount of information produced by the local mortality investigation committees allows the identification of factors associated with SB and provides guidelines for more effective prevention in the coverage area. ${ }^{8}$

Therefore, in view of its relevance, our objective is to describe the conditions associated with SB in a maternity hospital school located in the North zone of the city of São Paulo and the epidemiological trends in the last 15 years.

\section{Methods}

This is a cross-sectional observational study conducted at Hospital e Maternidade-escola Vila Nova Cachoeirinha (HMEC), located in the North zone of the city of São Paulo. The design of the study followed the Strenghtening the Reporting of Observational Studies in Epidemiology (STROBE) $^{9}$ statement, and it included 1,139 cases of SB attended in the period from 2003 to 2017. In view of some registry failures during the data collection, the total number of cases will be different in some variables.

The evaluation of all SBs was based on data from the perinatal mortality committee of the HMEC, using clinical information, notes available in the prenatal folder, maternal laboratory tests and necropsy in SB fetuses, and studies of placenta. The SB definition is according Brazil Ministry of Health based on weight, which defines SB as a death that occurs in any fetus weighing $500 \mathrm{~g}$ or more. To allow for international comparisons, we divided the general population according to the birth weight in two groups: intermediate stillbirths (ISBs), those with birth weight between 500 and $999 \mathrm{~g}$, and late stillbirths (LSBs), which consider fetus with $1,000 \mathrm{~g}$ or more. ${ }^{7}$

The following variables were selected: age group; number of pregnancies, prenatal care; number of prenatal visits, presence of fetal vitality at admission in hospital; characteristics of birth (site and type of birth), onset of labor, placenta study and necropsy of fetus. The associated causes related to SB were evaluated in addition to the historical evolution of the most frequent reasons, and SB coefficients.

All data was stored in Windows Excel (Microsoft Corp., Redmond, WA, USA) worksheets, and graphs and tables were then constructed based on them. We used the statistical software SPSS for Windows, version 18.0 (SPSS Inc., Chicago, IL, USA) to estimate the prevalence ratio (PR) and odds ratio (Odds), considering the $95 \%$ confidence interval $(95 \% \mathrm{CI})$.

The project was approved by the Ethics and Research Committee of HMEC (Reference No. 787.747), according to Resolution No. 466/2012 of the National Health Council (CONEP, in the Portuguese acronym).

\section{Results}

During the study period, the total number of live births in the HMEC was 95,650, and the number of SBs was 1,139, resulting in a stillbirth rate (SBR) of 11.9 per 1,000 . Taking into account only the cases of fetal deaths that occurred after
Table 1 Annual distribution of live births, total number of stillbirths, general stillbirth rate and in-hospital stillbirth rate (Maternity School of Vila Nova Cachoeirinha 2003-2017)

\begin{tabular}{|l|l|l|l|l|}
\hline YEAR & $\begin{array}{l}\text { LIVE BIRTHS } \\
(\mathbf{n})\end{array}$ & $\begin{array}{l}\text { STILLBIRTHS } \\
(\mathbf{n})\end{array}$ & SBR $^{*}$ & IHSR $^{*}$ \\
\hline 2003 & 4,596 & 88 & 18.8 & 6.0 \\
\hline 2004 & 5,973 & 87 & 14.3 & 3.1 \\
\hline 2005 & 5,129 & 75 & 14.4 & 4.2 \\
\hline 2006 & 5,180 & 52 & 9.9 & 2.8 \\
\hline 2007 & 5,980 & 61 & 10.1 & 3.0 \\
\hline 2008 & 5,973 & 73 & 12.1 & 3.8 \\
\hline 2009 & 6,053 & 83 & 13.5 & 3.2 \\
\hline 2010 & 6,205 & 51 & 8.1 & 1.4 \\
\hline 2011 & 7,022 & 63 & 8.9 & 1.7 \\
\hline 2012 & 7,763 & 79 & 10.1 & 1.6 \\
\hline 2013 & 7,592 & 95 & 12.3 & 1.7 \\
\hline 2014 & 7,189 & 82 & 11.2 & 1.8 \\
\hline 2015 & 6,867 & 92 & 13.2 & 2.9 \\
\hline 2016 & 6,820 & 78 & 11.3 & 2.9 \\
\hline 2017 & 7,308 & 80 & 10.8 & 1.9 \\
\hline TOTAL & 95,650 & 1,139 & 11.93 & 2.8 \\
\hline
\end{tabular}

Abbreviations: SBR, general stillbirth rate; IHSR, in-hospital stillbirth rate. *per 1,000

hospitalization, the coefficient of in-hospital stillbirth (IHSR) was 2.8 per 1,000 . (-Table $\mathbf{1}$ ).

in this table, it is also possible to observe that, over the years, the demand for HMEC care has been increasing. When comparing numbers from 2003 to those of 2017, there was a 59.9\% increase in the number of live births. Over the years, despite of the expansion in the number of live births, we can see stable institutional trends in both SBR and IHSR ( - Graphic $\mathbf{1}$ ).

When analyzing maternal and perinatal variables ( - Table 2), we observed that patients younger than 16 years and over 40 years represented $2.2 \%$ and $4.4 \%$ of the general population, respectively. However, pregnant women younger than 16 years old were more likely to have ISB (OR of 0.32 , 0.15-0.75), while patients over 40 years of age presented a higher chance of LSB (PR 0.85, 0.72-0.99). Women at first pregnancy comprised $37.5 \%$ of the population, and this group showed greater chances of ISB (PR 0.79; 0.67- 0.93), while women with more than 5 pregnancies represented $13.4 \%$ of the total population with a higher probability of presenting LSB (PR 0.87, 0.78-0.97). Regarding prenatal care, we found that $25.7 \%$ of the population had no prenatal visits, a similar distribution for both groups. However, when evaluating the number of visits performed between the patients who had prenatal care, $31.2 \%$ presented at least 6 visits, and this possibility was more frequent among the patients who had LSB (OR 4.56, 3.23- 6.44).

As for the presence of fetal vitality at hospital admission, $77.1 \%$ of the cases already presented fetal death in the initial care, and this possibility was more likely to occur among the 


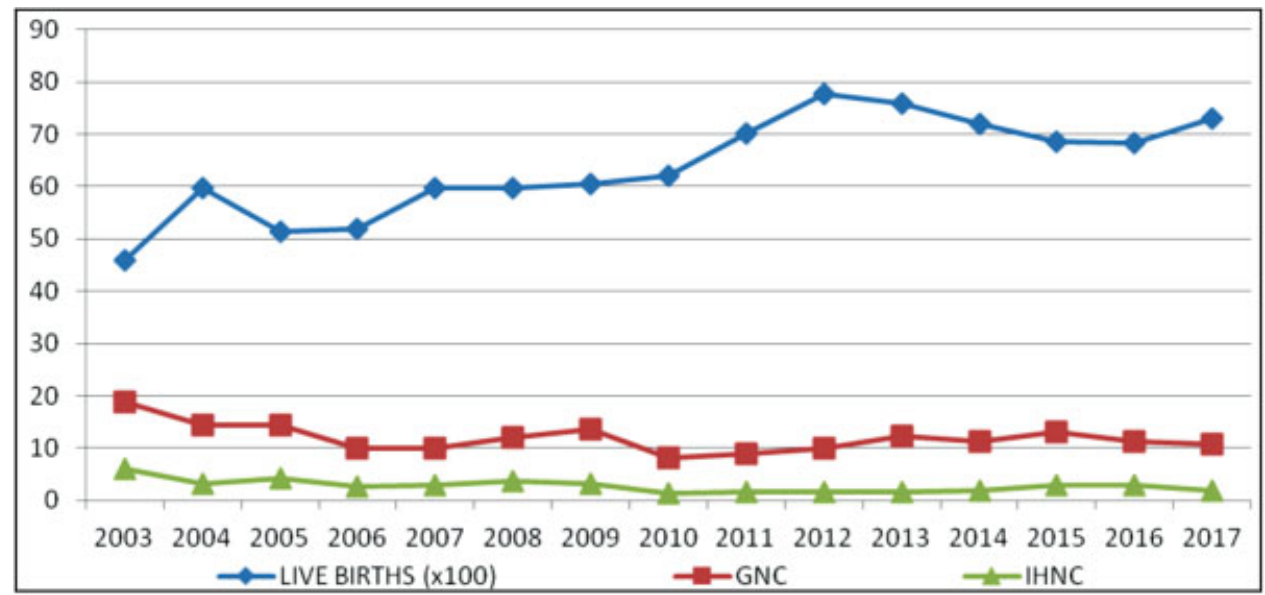

Graphic 1 Annual distribution of live births, general stillbirth coefficient (GSBC) and intrahospitalar stillbirth coefficient (IHSBC). (Maternity School of Vila Nova Cachoeirinha 2003-2017)

LSB group (OR 0.45, 0.34-0.59). In $96.0 \%$ of the cases, the births have occurred at the hospital, but ISB cases were more likely to occur at home (OR 0.42, 0.23-0.75). The labor was already installed in $66.3 \%$ of the general population, and this distribution was similar in both groups. Among the patients who underwent induction of labor, vaginal misoprostol was the most commonly used method. Regarding the type of delivery, cesarean section was performed in $16.1 \%$ of the cases, and the LSB group had a higher chance of this type of delivery (OR 2.53, 1.68-3.79).

Regarding the possibility of research support being complemented by necropsy and/or placenta study, both the ISB and LSB groups had a similar distribution, with $94.2 \%$ and $97.3 \%$, respectively. When we observe the factors associated with fetal deaths, - Table 3 shows the main causes according to frequencies. Despite the research methods used, in $22.1 \%$ of the study population, the possible cause of fetal death was not identified. This distribution was similar for both ISB and LSB groups. In the same table we can identify the main causes associated with fetal deaths:: infections of the amniotic sac and membranes (27.9\%), fetal malformations (12.5\%), placental abruption (11.2\%), hypertensive syndromes (8.5\%), and syphilis (3.9\%).

The comparison between the groups showed that the ISB group had higher chances for infection (OR 0.74, 0.56-0.97) and hypertensive syndromes (OR 0.49, 0.27-0.83). On the other hand, the LSB group had higher chances for placental abruption (1.72, 1.12-2.65) and diabetes mellitus (9.38; 1.25-70.55). Regarding syphilis, we found a similar distribution in the groups; however, with a higher prevalence ratio among the LSB patients $(0.83 ; 0.71-0.96)$.

Trends concerning the five main causes associated with SB, related to the period of the present study, show some stability, despite of alternations over time (Fig. 2), except for amniotic sac and membranes infections, which shows a decresing trend when comparing the initial evaluation from the first years of the study to the evaluation of the last years. The most important aspect to highlight is the increase in maternal syphilis from the year 2013 on, remaining at an outstanding level compared with the previous years (Fig. 2).

\section{Discussion}

According to the Ministry of Health of Brazil, SB remains an important public health problem, with stagnant numbers. From 1996 to 2006, the GSBC remained above $10.0 \%$, with regional disparities and worse results in the North and Northeast regions. ${ }^{7}$

Data available in the Tabnet system of the Municipal Health Department of the city of São Paulo shows that, between 2010 and 2016, the total number of fetal deaths in the Northern region of São Paulo is still stable, with around 250 SBs every year. It is important to mention that HMEC attends $25.8 \%$ of all cases in the region. ${ }^{9,10}$ The set of information provided in this study may be useful for understanding the key factors associated with fetal deaths occurring in this region and supporting strategic measures to reduce their impact on public health.

Maternal age is a single factor associated with adverse pregnancy outcomes, including intrauterine growth restriction (IUGR), preeclampsia, and placental abruption. ${ }^{11,12} \mathrm{~A}$ study performed in the Northeast region of Brazil showed that advanced maternal age persists as an independent factor related to $\mathrm{SB} .{ }^{13}$

In the present study, the total number of cases occurred in women of the age group considered adequate for gestation. Although the extremes of age may be a risk factor, the attributable contribution of this population to SB is relatively small. However, the age group under 16 years old presented a higher ISB than LSB rate, suggesting an earlier exposure to risk factors. At the other extreme age group, we observed that pregnant women older than 40 years were more likely to develop LSB, a fact that is possibly associated with a greater range of exposure to factors associated with fetal death, such as maternal diseases and fetal malformations.Therefore, family planning programs could add this message for both age groups.

The number of pregnancies seems to be a risk factor associated with SB, as documented in a multinational study that identified higher risks related to both the first pregnancy and to pregnant women with more than five previous deliveries. ${ }^{14}$

Our population follows the same pattern, but first pregnancy showed a higher ISB rate, while patients with five or more 
Table 2 Maternal and perinatal characteristics related to stillbirth. Prevalence rates and odds ratio (Maternity School of Vila Nova Cachoeirinha 2003-2017)

\begin{tabular}{|c|c|c|c|c|c|c|c|c|c|}
\hline & \multicolumn{3}{|l|}{ ISB } & \multicolumn{3}{|l|}{ LSB } & \multicolumn{2}{|l|}{ TOTAL } & \multirow[t]{2}{*}{ OR } \\
\hline & $\mathrm{N}$ & $\%$ & PR ISB & $\mathrm{N}$ & $\%$ & PR ISB & $\mathrm{N}$ & $\%$ & \\
\hline \multicolumn{10}{|l|}{ Age group } \\
\hline$<16$ years & 15 & 3.9 & $0.55^{*}(0.39-0.77)$ & 10 & 1.3 & $1,67^{*}(1.03-2.70)$ & 25 & 2.2 & $0.32 *(0.15-0.757)$ \\
\hline$\geq 16$ years & 366 & 96.1 & & 734 & 98.7 & & 1,100 & 97.8 & \\
\hline Total & 381 & 100.0 & & 744 & 100.0 & & 1,125 & 100.0 & \\
\hline$<40$ years & 370 & 97.1 & $1.53(0.90-2.59)$ & 706 & 94.9 & $0.85^{*}(0.72-0.99)$ & 1,076 & 95.6 & $1.81(0.92-3.58)$ \\
\hline$\geq 40$ years & 11 & 2.9 & & 38 & 5.1 & & 49 & 4.4 & \\
\hline Total & 381 & 100.0 & & 744 & 100.0 & & 1,125 & 100.0 & \\
\hline \multicolumn{10}{|l|}{$\begin{array}{l}\text { Number of } \\
\text { gestations }\end{array}$} \\
\hline 1 & 166 & 43.1 & $0.79 *(0.67-0.93)$ & 257 & 34.6 & $1.13^{*}(1.04-1.24)$ & 423 & 37.5 & $0.69 *(0.54-0.89)$ \\
\hline$\geq 2$ & 219 & 56.9 & & 486 & 65.4 & & 705 & 62.5 & \\
\hline Total & 385 & 100.0 & & 743 & 100.0 & & 1,128 & 100.0 & \\
\hline$<5$ & 346 & 89.9 & $1.37^{*}(1.03-1.82)$ & 631 & 84.9 & $0.87^{*}(0.78-0.97)$ & 977 & 86.6 & $1.57^{*}(1.07-2.32)$ \\
\hline$\geq 5$ & 39 & 10.1 & & 112 & 15.1 & & 151 & 13.4 & \\
\hline Total & 385 & 100.0 & & 743 & 100.0 & & 1,128 & 100.0 & \\
\hline \multicolumn{10}{|l|}{ Prenatal care } \\
\hline No & 92 & 25.8 & $1.01(0.83-1.22)$ & 181 & 25.6 & $0.99(0.90-1.10)$ & 789 & 74.3 & $1.01(0.75-1.35)$ \\
\hline Yes & 264 & 74.2 & & 525 & 74.4 & & 273 & 25.7 & \\
\hline Total & 356 & 100.0 & & 706 & 100.0 & & 1,062 & 100.0 & \\
\hline \multicolumn{10}{|c|}{ Appointments } \\
\hline$<6$ & 310 & 87.1 & $3.05^{*}(2.30-4.04)$ & 421 & 59.6 & $0.67^{*}(0.62-0.72)$ & 731 & 68.8 & $4.56^{*}(3.23-6.44)$ \\
\hline$\geq 6$ & 46 & 12.9 & & 285 & 40.4 & & 331 & 31.2 & \\
\hline Total & 356 & 100.0 & & 706 & 100.0 & & 1,062 & 100.0 & \\
\hline \multicolumn{10}{|c|}{$\begin{array}{l}\text { Fetal heartrate } \\
\text { at admission }\end{array}$} \\
\hline Absent & 259 & 67.3 & $0.61^{*}(0.52-0.72)$ & 612 & 82.2 & $1.37^{*}(1.21-1.55)$ & 871 & 77.1 & $0.45^{*}(0.34-0.59)$ \\
\hline Present & 126 & 32.7 & & 133 & 17.8 & & 259 & 22.9 & \\
\hline Total & 385 & 100.0 & & 745 & 100.0 & & 1,130 & 100.0 & \\
\hline \multicolumn{10}{|l|}{ Place of birth } \\
\hline Non-hospital & 25 & 6.5 & $0.61^{*}(0.46-0.80)$ & 21 & 2.8 & $1.46^{*}(1.07-2.01)$ & 46 & 4.0 & $0.42^{*}(0.23-0.75)$ \\
\hline In hospital & 362 & 93.5 & & 731 & 97.2 & & 1,093 & 96.0 & \\
\hline Total & 387 & 100.0 & & 752 & 100.0 & & 1,139 & 100.0 & \\
\hline \multicolumn{10}{|c|}{ Onset of labor } \\
\hline Spontaneous & 261 & 67.4 & $1.05(0.88-1.25)$ & 494 & 65.8 & $0.97(0.89-1.06)$ & 755 & 66.3 & $1.08(0.83-1.40)$ \\
\hline Induction** & 126 & 32.6 & & 257 & 34.2 & & 383 & 33.7 & \\
\hline Total & 387 & 100.0 & & 751 & 100.0 & & 1,138 & 100.0 & \\
\hline \multicolumn{10}{|l|}{ Type of birth" } \\
\hline Normal & 330 & 91.2 & $1.98 *(1.43-2.74)$ & 587 & 80.3 & $0.78^{*}(0.72-0.85)$ & 917 & 83.9 & $2.53^{*}(1.68-3.79)$ \\
\hline Cesarean & 32 & 8.8 & & 144 & 19.7 & & 176 & 16.1 & \\
\hline Total & 362 & 100.0 & & 731 & 100.0 & & 1,093 & 100.0 & \\
\hline \multicolumn{10}{|l|}{ Necropsy } \\
\hline Yes & 362 & 95.5 & $0.77(0.51-1.17)$ & 690 & 93.6 & $1.12(0.96-1.31)$ & 1,052 & 94.2 & $0.69(0.39-1.22)$ \\
\hline No & 17 & 4.5 & & 47 & 6.4 & & 64 & 5.8 & \\
\hline Total & 379 & 100.0 & & 737 & 100.0 & & 1,116 & 100.0 & \\
\hline
\end{tabular}


Trends Associated with Stillbirth in a Maternity Hospital School in the North Zone of São Paulo de Mendonça

Table 2 (Continued)

\begin{tabular}{|l|l|l|l|l|l|l|l|l|l|}
\hline & \multicolumn{3}{|l|}{ ISB } & \multicolumn{2}{l|}{ LSB } & \multicolumn{2}{l|}{ TOTAL } & OR \\
\hline & N & $\%$ & PR ISB & N & $\%$ & PR ISB & N & $\%$ & \\
\hline $\begin{array}{l}\text { Study of } \\
\text { placenta }\end{array}$ & & & & & & & & & \\
\hline Yes & 291 & 98.0 & $0.75(0.38-1.50)$ & 514 & 97.0 & $1.14(0.88-1.48)$ & 805 & 97.3 & $0.66(0.26-1.71)$ \\
\hline No & 6 & 2.0 & & 16 & 3.0 & & 22 & 2.7 & \\
\hline Total & 297 & 100.0 & & 530 & 100.0 & & 827 & 100.0 & \\
\hline
\end{tabular}

Abbreviations: ISB, immediate stillbirth; LSB, late stillbirth; N, number; OR, odds ratio; PR, prevalence ratio.

*Significance (95\% confidence interval)

\#Only in hospital.

${ }^{* *}$ Misoprostol was the option to ripening cervix in $81.7 \%$ of cases.

Table 3 Frequencies and causal factors attributed to intermediate stillbirth and late stillbirth (Maternity School of Vila Nova Cachoeirinha 2003-2017)

\begin{tabular}{|l|l|l|l|l|l|l|l|l|l|}
\hline $\begin{array}{l}\text { ATTRIBUTED } \\
\text { FACTORS }\end{array}$ & \multicolumn{2}{l}{ ISB } & \multicolumn{2}{l|}{ LSB } & \multicolumn{2}{l|}{ TOTAL } & \\
\hline & $\mathrm{N}$ & $\%$ & PR ISB & $\mathrm{N}$ & $\%$ & $\mathrm{PR}$ LSB & $\mathrm{N}$ & $\%$ & OR \\
\hline $\begin{array}{l}\text { Infections } \\
\text { (amniotic sac } \\
\text { and membranes) }\end{array}$ & 122 & 32.0 & $0.82^{*}(0.69-0.98)$ & 193 & 25.8 & $1.11(1.01-1.23)$ & 315 & 27.9 & $0.74^{*}(0.56-0.97)$ \\
\hline Indeterminate & 89 & 23.4 & $0.93(0.77-1.12)$ & 160 & 21.4 & $1.04(0.94-1,15)$ & 249 & 22.1 & $0,89(0.67-1.20)$ \\
\hline Fetal malformation & 44 & 11.5 & $1.09(0.84-1,42)$ & 97 & 13.0 & $0.96(0.85-1.08)$ & 141 & 12.5 & $1.14(0.78-1.67)$ \\
\hline Placental abruption & 30 & 7.9 & $1.47^{*}(1.06-2.03)$ & 96 & 12.9 & $0.85^{*}(0.77-0,95)$ & 126 & 11.2 & $1.72^{*}(1.12-2,65)$ \\
\hline $\begin{array}{l}\text { Hypertensive } \\
\text { syndrome }\end{array}$ & 47 & 12.3 & $0,66^{*}(0,53-0.83)$ & 49 & 6.6 & $1,32^{*}(1,08-1.62)$ & 96 & 8.5 & $0.49^{*}(0.27-0.83)$ \\
\hline Syphilis & 9 & 2.4 & $1.68(0.93-3.02)$ & 35 & 4.7 & $0.83^{*}(0.71-0.96)$ & 44 & 3.9 & $2.03(0.97-4.27)$ \\
\hline $\begin{array}{l}\text { Umbilical } \\
\text { cord changes }\end{array}$ & 12 & 3.1 & $1.19(0.73-1.93)$ & 30 & $4 ., 9$ & $0.92(0.76-1.12)$ & 42 & 3.7 & $1.29(0.65-2.54)$ \\
\hline $\begin{array}{l}\text { Other placentary } \\
\text { disorders }\end{array}$ & 14 & 3.7 & $0.96(0.63-1.48)$ & 26 & 3.5 & $1.02(0.81-1,28)$ & 40 & 3.5 & $0.94(0.49-1.83)$ \\
\hline $\begin{array}{l}\text { Fetal-fetal } \\
\text { transfusion } \\
\text { syndrome }\end{array}$ & 6 & 1.6 & $1.42(0.70-2.86)$ & 19 & 2.5 & $0,87(0.69-1.09)$ & 25 & 2.2 & $1.63(0.65-4.12)$ \\
\hline Diabetes mellitus & 1 & 0.3 & $6.51(0.96-43.94)$ & 18 & 2.4 & $0.69^{*}(0.62-0.78)$ & 19 & 1.7 & $9.38^{*}(1.25-70.55)$ \\
\hline Other causes & 5 & 1.3 & $1.36(0.63-2.91)$ & 15 & 2.0 & $0.88(0.68-1.14)$ & 20 & 1.8 & $1.54(0.54-4,27)$ \\
\hline TOTAL & 381 & 100.0 & & 747 & 100.0 & & 1,128 & 100.0 & \\
\hline
\end{tabular}

Abbreviation: ISB, immediate stillbirth; LSB, late stillbirth; N, number; OR, odds ratio; PR, prevalence ratio.

*Significance ( $95 \%$ confidence interval)

pregnancies are associated to higher LSB risk. Despite these findings, the association of maternal parity and the risk of fetal death should be interpreted with caution, considering that confounding factors may limit this conclusion. ${ }^{4,14}$ It should be added that the higher the number of pregnancies, the greater the chance of exposure, following the same logic applied to maternal age.

Regarding prenatal care, the literature is unanimous in considering the qualification of this follow-up of pregnancy as essential for the reduction of maternal and perinatal risks in order to achieve good results. According to the Brazilian Program for Humanization of Prenatal and Childbirth, and to the World Health Organization, the occurrence of SBs is higher among women whose prenatal care was considered inadequate. ${ }^{15,16}$
This statement is confirmed by one study conducted in the Southern region of Brazil, where inadequate prenatal was associated with the occurrence of SB. ${ }^{17}$ In the present study, we found that among the total number of cases, $25.7 \%$ did not attend any prenatal visits. This expressive rate reveals that many opportunities for intervention probably were lost in order to reduce the risk of fetal death. This concerning situation was similar in both groups.

Regarding the number of prenatal care visits, it seems reasonable that the ISB group would have fewer consultations, since fetal death occurred in the earlier stages of pregnancy. However, even in the LSB group, $68.8 \%$ of the cases had less than 6 visits. Perhaps, the same logic applies in this case, and it is reasonable to assume that the number of visits, per se, does 
not seem to be associated with the occurrence of SB cases but rather their initial qualification. This aspect deserves special attention because the notes in the prenatal cards are essential for identifying possible factors related to SB. Therefore, strategic actions directed to ensure accessibility to medical care as soon as possible, their initial qualification. In addition, in many cases, the quality of the information available in the prenatal records presented at the time of hospitalization does not help to elucidate the causes of SB.

Although it is possible to understand that the risk of SB is reduced by means of qualified care actions, it should be considered that identifying the moment of the fetal death is a very difficult task. Biological determinisms are complex and, often, not identified in a timely manner. In addition, SB may be the result of different etiologies and not of a single disorder, and it is unlikely that any individual test will be able to predict fetal death and identify all causes. ${ }^{18}$ In any case, the SB among hospitalized patients is important to identify possible assistance failures in situations that can be prevented.

We identified that, in the total population, fetal heartbeats were absent at the time of hospital admission in $77.1 \%$ of the cases. When comparing the groups, we found out that the ISB group had higher chances of fetal death occurring during hospitalization. We believe that this fact may be associated with institutional characteristics, since HMEC is a reference center to high-risk pregnancies, where several patients remain under institutional care until reaching viable gestational age. Although this phenomenon may occur, it did not significantly affect the evolution of IHSR (in-hospital stillbirth rate) throughout our historical series (-Graphic $\mathbf{1}$ ).

Regarding delivery care, in $96.0 \%$ of all cases, births have occurred in the hospital environment, and, among them, $66.3 \%$ of the cases were admitted in spontaneous labor. Cases requiring cervix ripening received intravaginal misoprostol or endocervix Foley catheter, but misoprostol was the more common method used in $81.7 \%$ of the cases.

However, a notable fact is that non-hospital births occurred in $4.0 \%$ of the population, and the ISB group had greater chances of this type of occurrence. The dramaticity of these situations must be emphasized considering the additional exposure of these women to the risks of severe bleeding and infection. These occurrences were more frequent among the ISB group, but we did not identify a related factor other than the possibility of a smaller fetal volume facilitating their expulsion.

For the care of pregnant women with SB, the indication of cesarean section only makes sense when maternal risks outweigh the benefits, such as instability imposed by placental abruption or risks of uterine rupture. ${ }^{14}$

When evaluating the overall cesarean section rates, it is verified that this occurred in $15.4 \%$ of the cases, which allows us to state that they are within the guidelines of care. It is necessary to consider that the main cases of cesarean section were placental abruption, and patients with scars, in whose case the risks of uterine rupture were not negligible. The characteristics of labor assistance verified in our series can provide two topics for obstetric practice: the first is a strong recommendation that vaginal birth is the preferential option for these situations, considering maternal risks. The second refers to the use of misoprostol in adequate doses, and the respect to the time necessary for the onset of labor. ${ }^{19}$

The task of investigating and identifying factors associated with SB remains as an important point to understand this dramatic outcome and to provide alternatives for prevention and counseling. ${ }^{20}$ Even with several alternatives available for research, many causes remain unknown. ${ }^{21}$ In this scenario, the anatomopathological evaluation of the fetus and placenta may be valuable in elucidating the case. This practice is still not widely adopted and is identified by some authors in only 30.0 to $35.0 \%$ of occurrences. ${ }^{17,20}$

In our study, both placenta and fetal studies were performed in expressive percentage ( - Table 2 ) and assisted in the definition of the associated cause. Nevertheless, $22.1 \%$ of the cases remained as unidentified etiology, with this aspect being similar between the groups. Not having the answer that clarifies a SB is a frustrating experience for the family and the medical staff. Thus, the entire diagnostic arsenal (clinical, imaging, laboratory and pathological anatomy) should be used to elucidate the cause of fetal death. ${ }^{22}$ However, in many cases, severe fetal maceration limits a more detailed study of the corpse.

During the study period, there were many factors associated with SB, with some alternations occurring during the years of study (Fig. 2). Amniotic sac and membranes infections had an expressive participation in our sample and was often identified only by the placenta study, in which we can identify chorioamnionitis, frequently associated with funisitis.

Infections can cause SB through several mechanisms, including direct fetal infection, placental injury, and severe maternal illness. Many bacteria, viruses and protozoa have been associated with SBs. In developed countries, up to $24.0 \%$ of the cases of SB were attributed to some infection. Thus, screening of maternal infectious processes at sites such as the urinary tract, teeth, and vagina would possibly reduce their impact on the causes of SB. However, to implement these actions is not an easy task in our health system. Regarding fetal anomalies, all conditions were grouped. This group of reasons was associated in $12.5 \%$ of the general population, with a similar distribution between ISB and LSB ( - Table 3 ). Differently from our results, a study in Southern Brazil that reviewed autopsy records of all SBs $(n=111)$ in one hospital reported that $26.0 \%$ of SBs were caused by congenital anomalies. Although studies that evaluate risks indicate that fetal anormalities have strong association with SB, frequencies are very diverse in the literature, ranging from 2.1 to $33.3 \%$. Such differences are most likely related to the various clinical profiles of the institutions where the cases are studied. Centers with a high concentration of this type of problem may have relevant rates in their indicators, but this cannot be transferred to the general population. ${ }^{4,23-28}$

Placental abruption is recognized as one of the main causes of fetal death, with a percentage attribution between 7.5 and $42.0 \%{ }^{4}$ Moreover, it is worth mentioning that this condition imposes a higher maternal risk, given its emergency character, with a quick hemodynamic failure of the woman. Besides, there is a very frequent need for cesarean delivery due to the uncertainty of fetal vitality, adding more risks to the care of these patients. The higher chances of this serious obstetric 
condition were associated with LSB cases. In view of the dramatic condition of placental abruption and uterine hypertonia, evaluation of fetal conditions is a very difficult task. Therefore, it is understandable that in this singular situation, the rate of cesarean section is higher in view of the uncertainty of fetal death. This is why cesarean birth is the best option when facing such dramatic situations.

The risk of fetal death increases in hypertensive patients, with chronic hypertension and preeclampsia being included in this category, due to varying degrees of placental insufficiency and IUGR in addition to acute events, such as placental abruption. $^{23}$

On a global scale, it is estimated that 2.6 million SBs occur annually around the world and $\sim 16.0 \%$ of them occur in pregnancies complicated by gestational hypertension. ${ }^{24}$ In the present study, $8.5 \%$ of the SB cases had hypertensive syndrome as their main cause. It is added that placental abruption, often associated with patients with hypertensive disorders, was also an important cause during the study period (-Table 3 ).

The highest chances of this association were identified among cases of ISB. Possibly, this fact could be explained by the presence of patients in the high-risk unit in the very early stages of gestation, when the expectant management is adopted to improve the prognosis of the newborn in view of extreme prematurity.

Considering that when it comes to hypertension, maternal and perinatal outcomes are directly related to the quality of prenatal care, it would be important to adopt prevention and early detection actions. This would have a positive impact on the reduction of severe cases and on early identification of placental insufficiency, thus allowing more timely actions.

A very concerning condition was the identification of syphilis as responsible for 3.9\% of SBs in our population, with a more significant prevalence among the LSB group. In addition, we noticed an increasing trend in its prevalence since 2013 (Fig. 2).
It is estimated that, each year, between 1 and 2 million pregnancies are affected by syphilis in the world. Among the adverse perinatal outcomes in infected pregnant women, we highlight fetal death, which may occur in 30.0 to $40.0 \%$ of the cases. A study related to syphilis, conducted in the Americas, has shown that positive sorology has a 6.8-fold higher chance of SB compared with healthy women. ${ }^{29}$

From 2005 to June 2017, 200,253 cases of syphilis were reported in pregnant women in Brazil, $44.2 \%$ of whom were residents of the Southeast region. ${ }^{30}$ The increase in the number of cases recorded in our study probably runs parallel with the syphilis epidemic detected by the national health authorities.

This constant increase in cases of syphilis in pregnant women may be related to several factors, such as greater coverage of testing, reduction of condom use, resistance of health professionals to the administration of penicillin in primary care, and shortages of penicillin. ${ }^{30}$

Preventing SB attributable to syphilis should be easier in contexts of high prevalence, considering that the diagnosis and treatment of the disease during pregnancy occurred effectively. ${ }^{29}$ Unfortunately, this does not seem to be happening.

Regarding the set of factors associated with SB, when evaluating the behavior of the frequencies over the period studied, we found that five factors concentrated the majority of the cases. - Graphic 2 illustrates that, over the years, amniotic sac and membranes infections defined as chorioamnionitis have tended to decline: in 2003, they accounted for $36.9 \%$ of the cases, and, in 2017 , this portion reached $25.0 \%$. We considered it a complex task to identify the reasons for this behavior, considering that we did not detect global assistance actions that could reduce the risks of maternal infection and its consequences.

Despite the persistence of the investigation criteria, indeterminate causes accounted for $22.1 \%$ of the cases, revealing difficulties in refining the research. Even with the resources currently available, we are far from a more advanced level of

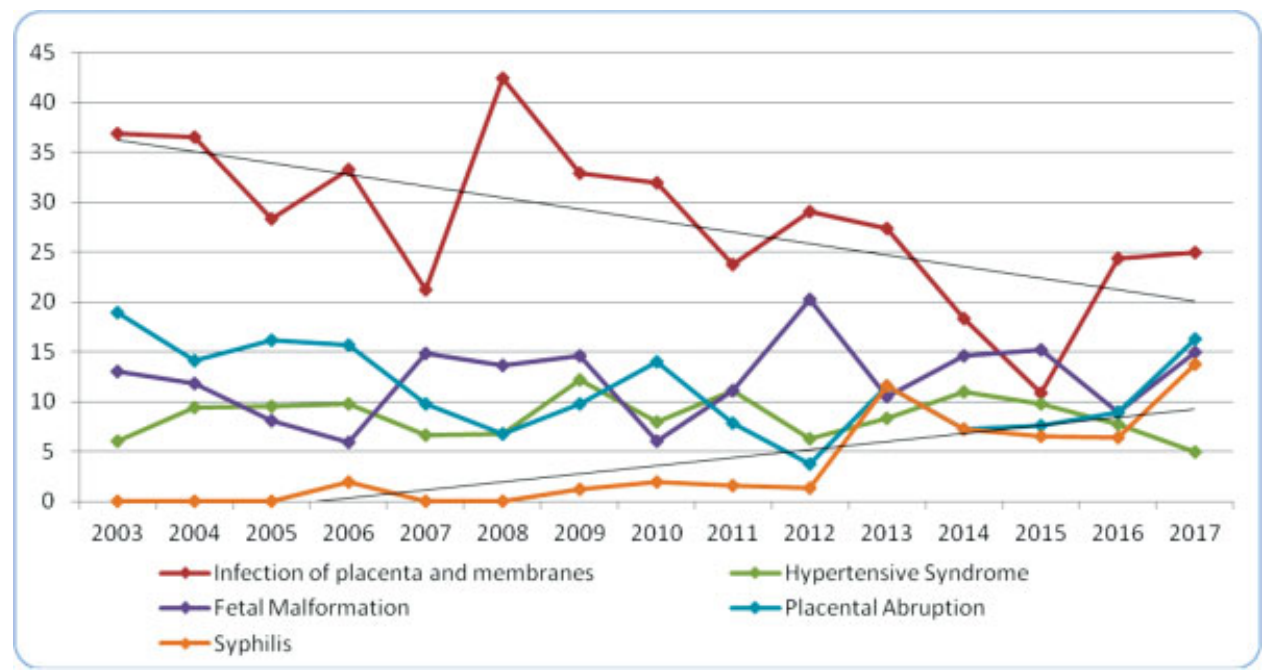

Graphic 2 Frequency of the main factors related to fetal deaths and trends. Maternity School of Vila Nova Cachoeirinha 2003-2017. (Maternity School of Vila Nova Cachoeirinha 2003-2017) 
research that may include cytogenetic studies, fetal tissue cultures, including viral research, screening for hereditary deficiencies, evaluation of fetal and/or placental hemorrhage, dosage of heavy metals and environmental pollutants, among others.

A standardized universal definition of SBs and their causes is a key issue, so that the methodological quality of SB research is improved. In addition, adopting international standardization for the classification of fetal deaths could facilitate comparisons between different regions and guide actions to reduce this phenomenon. ${ }^{22}$ More studies about SBs should be further explored by official statistics in view of their undoubted importance in terms of public health and valuable sentinel event of prenatal care quality. Limitations related to more diagnostic methodologies justify the maintenance of expressive rates of undiagnosed fetal deaths.

\section{Conclusion}

The present study evaluated a historical series of SB cases, and its methodology allowed identifying how these events occurred at the HMEC. Relevant aspects were identified, such as lack of prenatal care, home birth, and the use of misoprostol for labor induction. The factors associated to the SB presented a certain concentration, during the 15 years of study, particularly the role of infections of amniotic sac and membranes, fetal malformations, placental abruption, hypertensive syndromes, and maternal syphilis. In relation to syphilis, the tendency of growth in its frequency translates an alert in terms of sanitary problem.

\section{Contributions}

Each author participated actively in the planning, execution, and conduction of this study. The authors proposed the manuscript, edited, and approved the final version to be published.

\section{Conflicts of Interest}

The authors declare that there are no conflicts of interest.

\section{Acknowledgments}

The authors would like to thank Vitor Alexandre Melo Tavares and Isadora Magalhães for their support in the text management.

\section{References}

1 Frøen JF, Cacciatore J, McClure EM, et al; Lancet's Stillbirths Series steering committee. Stillbirths: why they matter. Lancet 2011; 377(9774):1353-1366. Doi: 10.1016/S0140-6736(10)62232-5

2 Lawn JE, Blencowe H, Pattinson R, et al; Lancet's Stillbirths Series steering committee. Stillbirths: Where? When? Why? How to make the data count?. Lancet 2011;377(9775):1448-1463. Doi: 10.1016/S0140-6736(10)62187-3

3 Ministério da Saúde. DATASUS: Tecnologia da Informação a Serviço do SUS Brasil. Óbitos Fetais. 2017http://tabnet.datasus.gov.br/cgi/ tabcgi.exe?sim/cnv/fet10uf.def. Accessed May 20, 2018.

4 Aminu M, Unkels R, Mdegela M, Utz B, Adaji S, van den Broek N. Causes of and factors associated with stillbirth in low- and middle-income countries: a systematic literature review. BJOG 2014;121(Suppl 4):141-153. Doi: 10.1111/1471-0528.12995
5 Cockerill R, Whitworth MK, Heazell AE. Do medical certificates of stillbirth provide accurate and useful information regarding the cause of death? Paediatr Perinat Epidemiol 2012;26(02):117-123. Doi: 10.1111/j.1365-3016.2011.01247.x

6 Barbeiro FM, Fonseca SC, Tauffer MG, et al. Fetal deaths in Brazil: a systematic review. Rev Saude Publica 2015;49:22. Doi: 10.1590/ S0034-8910.2015049005568

7 Ministério da Saúde. Secretaria de Vigilância em Saúde. Secretaria de Atenção à Saúde. Manual de Vigilância do Óbito Infantil e Fetal e do Comitê de Prevenção do Óbito Infantil e Fetal. 2ª ed. Brasília, DF: Ministério da Saúde; 2009

8 Fundação Oswaldo Cruz. Instituto de Comunicação e Informação Científica e Tecnológica em Saúde. PROADESS - Avaliação do Desempenho do Sistema de Saúde. Rio de Janeiro: Laboratório de Informação em Saúde/ICICT/Fiocruz; 2018https://www.proadess.icict.fiocruz.br/index.php?pag=res1. Accessed Jan. 06, 2019.

9 Malta M, Cardoso LO, Bastos FI, Magnanini MM, Silva CM. STROBE initiative: guidelines on reporting observational studies. Rev Saude Publica 2010;44(03):559-565. Doi: 10.1590/S0034-8910 2010000300021

10 Prefeitura de São Paulo. Secretaria de Saúde. TabNet Tecnologia DATASUS. Óbitos Fetais. 2018http://tabnet.saude.prefeitura.sp.gov. br/cgi/tabcgi.exe?secretarias/saude/TABNET/fetal/fetal. Accessed Jan. 06, 2019.

11 Lawn JE, Blencowe H, Waiswa P, et al; Lancet Ending Preventable Stillbirths Series study group; Lancet Stillbirth Epidemiology investigator group. Stillbirths: rates, risk factors, and acceleration towards 2030. Lancet 2016;387(10018):587-603. Doi: 10.1016/ S0140-6736(15)00837-5

12 Lean SC, Derricott H, Jones RL, Heazell AEP. Advanced maternal age and adverse pregnancy outcomes: A systematic review and meta-analysis. PLoS One 2017;12(10):e0186287. Doi: 10.1371/ journal.pone.0186287

13 Andrade LG, Amorim MMR, Cunha ASC, Leite SRF, Vital SA. [Factors associated with stillbirth in a school maternity in Pernambuco: a case control study]. Rev Bras Ginecol Obstet 2009;31 (06):285-292. Doi: 10.1590/S0100-72032009000600004

14 McClure EM, Pasha O, Goudar SS, et al; Global Network Investigators. Epidemiology of stillbirth in low-middle income countries: a Global Network Study. Acta Obstet Gynecol Scand 2011;90 (12):1379-1385. Doi: 10.1111/j.1600-0412.2011.01275.x

15 Tunçalp Ö, Pena-Rosas JP, Lawrie T, et al. WHO recommendations on antenatal care for a positive pregnancy experience-going beyond survival. BJOG 2017;124(06):860-862. Doi: 10.1111/ 1471-0528.14599

16 Ministério da Saúde. Programa Humanização do Parto: Humanização no Pré-Natal e Nascimento. Brasília, DF: Ministério da Saúde; 2002

17 Vardanega K, De Lorenzi DRS, Spiandorello WP, Zapparoli MF. [Risk factors for stillbirth at a Universitary Hospital in Southern Brazil] Rev Bras Ginecol Obstet 2002;24:617-622. Doi: 10.1590/ S0100-72032002000900008

18 Conde-Agudelo A, Bird S, Kennedy SH, Villar J, Papageorghiou AT. First- and second-trimester tests to predict stillbirth in unselected pregnant women: a systematic review and meta-analysis. BJOG 2015;122(01):41-55. Doi: 10.1111/1471-0528.13096

19 International Federation of Gynecology and Obstetrics (FIGO). Misoprostol Only-Recommended Regimens 2017. https://www.figo.org/ sites/default/files/uploads/project-publications/Miso/Misoprostol_Card_2017_EN.pdf. Accessed June 16, 2018.

20 Lamont K, Scott NW, Jones GT, Bhattacharya S. Risk of recurrent stillbirth: systematic review and meta-analysis. BMJ 2015;350: h3080. Doi: 10.1136/bmj.h3080

21 Fretts RC. Etiology and prevention of stillbirth. Am J Obstet Gynecol 2005;193(06):1923-1935. Doi: 10.1016/j.ajog.2005.03.074

22 Ibiebele I, Boyle FM, Horey D, et al. Predictors of autopsy following stillbirth in Queensland, Australia: A population-based study. 
Aust N Z J Obstet Gynaecol 2017;57(01):33-39. Doi: 10.1111/ ajo. 12563

23 Reddy UM, Goldenberg R, Silver R, et al. Stillbirth classificationdeveloping an international consensus for research: executive summary of a National Institute of Child Health and Human Development workshop. Obstet Gynecol 2009;114(04):901-914. Doi: 10.1097/AOG.0b013e3181b8f6e4

24 von Dadelszen P, Magee LA. Preventing deaths due to the hypertensive disorders of pregnancy. Best Pract Res Clin Obstet Gynaecol 2016;36:83-102. Doi: 10.1016/j.bpobgyn.2016.05.005

25 McClure EM, Dudley DJ, Reddy UM, Goldenberg RL. Infectious causes of stillbirth: a clinical perspective. Clin Obstet Gynecol 2010;53(03):635-645. Doi: 10.1097/GRF.0b013e3181eb6620

26 Vieira MSM, Siebert EC, Ceglio WQGW, Almeira MH, Batista TS, Freitas PF. [Difficulties for identification of cause of fetal death: how to solve?] Rev Bras Ginecol Obstet 2012;34(09):403-408. Doi: 10.1590/S0100-72032012000900003
27 Auger N, Park AL, Zoungrana H, McHugh NGL, Luo ZC. Rates of stillbirth by gestational age and cause in Inuit and First Nations populations in Quebec. CMAJ 2013;185(06):E256-E262. Doi: 10.1503/cmaj.120945

28 Boyle B, McConkey R, Garne E, et al. Trends in the prevalence, risk and pregnancy outcome of multiple births with congenital anomaly: a registry-based study in 14 European countries 1984-2007. BJOG 2013;120(06):707-716. Doi: 10.1111/14710528.12146

29 Arnesen L, Serruya S, Durán P. Gestational syphilis and stillbirth in the Americas: a systematic review and meta-analysis. Rev Panam Salud Publica 2015;37(06):422-429

30 Boletim Epidemiológico Aids e DST. Brasília (DF): Ministério da Saúde/Secretaria de Vigilância em Saúde/Programa Nacional de DST e Aids. 2017;48(36). http://www.aids.gov.br/pt-br/pub/ 2017/boletim-epidemiologico-de-sifilis-2017. Accessed May 22, 2018. 